\title{
Nationalism, politics, and the practice of archaeology
}

edited by

Philip L. Kohl and Clare Fawcett 


\section{Nationalism, politics, and the practice of archaeology in the Caucasus ${ }^{1}$}

\section{Philip L. Kohl and Gocha R. Tsetskhladze}

This chapter examines the politics of archaeology in an area that can justly be viewed either as part of the northern frontier of the modern Middle East (and ancient Near East) or the southeastern boundary of Europe (Map 2). One of the fascinations of Caucasia - both Ciscaucasia and Transcaucasia ${ }^{2}$ - is that it is a region where European (Christian) and Oriental (here Islamic) traditions meet or, more appropriately today, collide. It is also characterized by exceptional, almost unparalleled ethnic and linguistic diversity, making it - depending upon one's temperament - either an ethnographer's dream or nightmare.

In addition to sectarian, linguistic, and ethnic diversity, the Caucasus is characterized by a very long and vivid historical consciousness, extending back with rich historical and then archaeological documentation for millennia. Archaeology and ancient history are exceptionally alive and meaningful for all the myriad peoples of the Caucasus. Today, given the collapse of the former Soviet Union, it is a very volatile region replete with numerous territorial disputes and several exceptionally bloody and explosive ethnic conflicts. Given all these conditions, it is an area where one would not expect the practice of archaeology to be an idle academic pursuit, unrelated to contemporary politics. One is not disappointed.

This paper will demonstrate the political nature of archaeology in the Caucasus by relating several examples illustrating this fact, proceeding first regionally, considering interpretations of the prehistoric record in Azerbaijan, Georgia, Armenia, and the northern Caucasus, and then chronologically with an evaluation of Caucasian archaeological evidence for the classical period, particularly as it relates to Greek colonization in western Georgia, beginning in the mid-sixth century BC. As it proceeds, it will also attempt to establish criteria for distinguishing acceptable "readings" of Caucasian prehistory from serious "misreadings" or distortions of that past that may result in the systematic suppression, if not slaughter, of one people by another.

At the outset, we wish to emphasize that, while we are being critical of the practices of many local Caucasian archaeologists, this does not mean that 


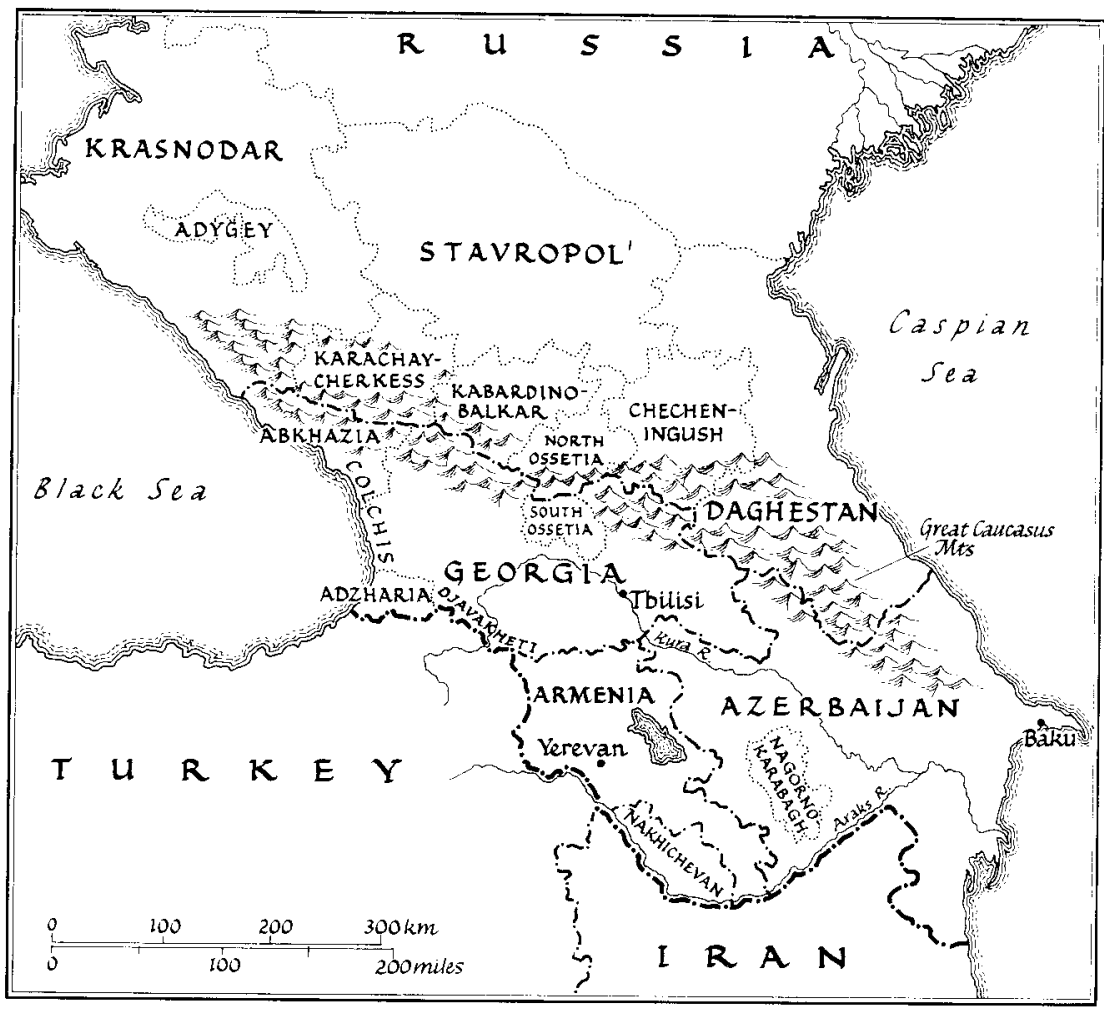

2 The Caucasus: political and administrative boundarics in 1991

we are not appreciative of their many substantive achievements in reconstructing their incredibly rich remote past; while we generalize critically about the behaviors of entire peoples (and as generalizations, there are, of course, numerous exceptions), this does not mean that we are at all demeaning or holding suspect the proud and distinctive cultural traditions that make the area so fascinating and intellectually stimulating. If we spend more time illustrating the questionable practices of archaeologists of one culture and fail to mention those of another, it is not a political statement of support for the latter on our part. Sadly, no group is above criticism. Current ethnic conflicts, based on territorial political disputes in the Caucasus and all too often justified by archaeological "readings" of an always deficient, never satisfactory record, are extremely complex and, unfortunately, lack simple solution.

We argue against an "essentialist" conception of culture, particularly as applied to the archaeological record. This view maintains that cultures are 
like minerals that have crystallized; once formed, they assume a distinctive shape that characterizes them "from time immemorial" to the present. An essentialist (or primordialist) view holds that Azeris, Armenians, Georgians, Ossetians, Abkhazians, Chechens, etc. have "always" existed in a manner that blurs necessary distinctions between culture, language, and race. This conception of culture, which is adopted consciously or not by most Caucasian archaeologists, is opposed to the view of cultures as constantly "in the making," historically rooted, open-ended systems which are continuously transforming themselves, borrowing from their neighbors, and being inextricably caught up in historical processes much larger than themselves (Wolf 1984; Kohl 1992:173-4).

Although one cannot try to reconstruct the past by ignoring the real and important phenomenon of ethnicity (itself a grossly underconceptualized causative factor in cultural evolution), one must be extremely circumspect in attempting to identify specific ethnic groups solely on their material culture remains. Sometimes, of course, such identifications - however tentatively - can be made, but even then one must examine critically what problems one is solving through such identifications and not fall into the trap of conceptualizing cultures with long historic and prehistoric traditions as crystallized Platonic essences, exhibiting all their current distinguishing features in remote antiquity. As sensible anthropologists, like E. Wolf (1982) and R. Fox (1985), and sensible historians, like E.P. Thompson (1966) and R.G. Suny (1988, 1993a), have reminded us: cultures are always in the process of changing and reconstituting themselves, sometimes in almost unrecognizable, qualitatively different ways. There is no culture that has existed "since time immemorial" and no people that is aboriginal in terms of their contemporary culture with a specific piece of real estate; ethnogenesis is a fact, but it does not imply that cultures exhibit forever the characteristics present at their birth.

\section{Contradictory "readings" of Caucasian prehistory A Azerbaijan}

Most accounts written in the Soviet period that summarize the prehistory and early history of Azerbaijan adopt a rather straightforward evolutionary perspective, stressing local indigenous development from Lower Palaeolithic times onwards (e.g., Geyushev 1986; Guseinov 1985; Muradova 1979). Although they minimize external influences, there is nothing inherently suspect in such accounts - until one is politically attuned to what may be omitted or implied, a practice that occurs in both scholarly reports and more popular accounts. The latter are more problematic, particularly 
in so far as they reach a broader, less discriminating audience. Thus, for example, a widely disseminated tourist guide to Baku (Agaev 1987:13) begins with the following assertion:

The tribes who inhabited this land in antiquity, the fore-runners of the Azerbaijani people, occupied a vast territory which included both Northern (now Soviet) and Southern (Iranian) Azerbaijan. Various parts of it became known after the tribes as Caspian. Mannai, Media, and Caucasian Albania. Some of the states which emerged in the area from the third millennium $\mathrm{BC}$ were powerful and relatively advanced, particularly Mannai and Media, the latter subjugating Assyria and Urartu among others.

Seemingly straightforward, this passage deserves critical scrutiny, particularly the phrase "fore-runners of the Azerbaijani people" and the implied cultural uniformity from Bronze Age times onwards of the entire area occupied today by Azeri peoples. The early historical cultures that are mentioned were certainly not directly related to the Turkic-speaking Azeris, and, while material cultural connections dating back at least to the third millennium BC (a much earlier time than the known period of existence for any of the specified cultures) link the area encompassing the Republic of Azerbaijan with that of northwestern Iran (what is called Iranian or southern Azerbaijan), it is debatable that such north-south connections were stronger or formed a greater unity than those, say, stretching east-west across Transcaucasia. In other words, the implication of this passage is that the area dominantly inhabited by Azeris, which today is politically divided into northern and southern parts, was originally united, that it naturally forms a coherent cultural whole. The political implications of the passage become clear when one considers recent history: one of the first confrontations of the Cold War, the slow withdrawal of Red Army troops from northwestern Iran in the wake of the Second World War; the demographic dominance of southern Azerbaijan; and, even more, certain inflammatory statements of the former President of Azerbaijan, A. Elchibey, ${ }^{3}$ regarding Azerbaijan's right to control areas populated dominantly by Azeris (i.e., northwestern Iran).

More precisely. what is a relatively innocuous statement in one political context may become charged with political significance in a different context or as that context changes. A foreign archaeologist traversing this minefield of subtle political nuances must also be aware of what may be omitted from reviews of the prehistoric and historic record. Thus, for example, a popular overview to the development of the Autonomous Republic of Nakhichevan (Guliev et al. 1984) reviews the history of this region from prehistoric times to the present without once mentioning the Armenians despite the numerous cultural monuments that still silently 
testify to their millennia-old presence in, if not always political control over, the region (for documentation of the Armenian monuments from Nakhichevan, see Ayvazian 1990). ${ }^{4}$

The nominally Marxist evolutionary accounts that stress internal developments and minimize change wrought by incursions of different ethnic groups are, of course, not necessarily incorrect; the archaeological record frequently is ambiguous concerning the relative historical significance to be accorded internal and external factors, allowing more than one reasonable "reading" of that record. Nevertheless, the non-local archaeologist is better able to evaluate specific interpretations if he/she is conscious of the possible political implications of a specific "reading."

In a given context, emphasis on internal evolutionary development accords well with what we have termed the "essentialist" view of culture. Some Azeri archaeologists, who adopt this conception of culture, are excessively patriotic or chauvinistic of the land they today control. They are confronted with the uncomfortable historic fact that Turkic-speaking peoples, who became today's self-conscious Azeri ethnos, ${ }^{5}$ migrated into the area during historic times as part of the centuries-long movement of Turkish peoples from central Asia across Anatolia and into southeastern Europe. Other cultures, such as the Christian Albanian state of the early medieval period, are known to have occupied Azerbaijan prior to the arrival of the Turkic-speaking pastoral nomads. This great east-west movement which had profound consequences for world history is, of course, well documented historically and can be attested archaeologically (e.g., by the fields of pre-Islamic baba stone "idols" or stylized anthropomorphic statues over graves which serve as a marker for the movement of Turkic-speaking peoples east to west and which can be traced like a perfect sloping horizon from southern Siberia and eastern central Asia across the Eurasian steppes all the way to the borders of Azerbaijan (e.g., Burney 1979; Stronach 1981)). ${ }^{6}$ Nevertheless, some Azeri scholars adopt an extreme version of the essentialist view of Azeri culture by either denying the presence of non-Turkic cultures or seeing them all as Turkic-speaking; others more plausibly regard today's Azeris as an assimilated population with both "Albanian" and Turkic ancestors. Either view, however, can be slanted for nationalist purposes.

Why deny a history of physical and cultural assimilation that is at least centuries. if not millennia, old? In more pacific times, such denial could be excused as perhaps excessive attachment to the naturally rich region of eastern Transcaucasia. Assertion that the homeland of the Azeri nation, indeed of all Turkic peoples, ${ }^{7}$ was the area immediately east and south of the Caspian Sea can be just a harmless statement of faith reflecting considerable pride in and devotion to the land they now occupy. 
Apparently innocuous were other contradictory and/or incredible myths related by professional archaeologists that claimed that the Scythians were Turkic-speaking and that the script of the early first millennium AD Albanian state - under whose sway real history first dawns in eastern Transcaucasia - was written in Turkish.

A more critical evaluation of this misplaced pride in cultural origins, however, is warranted, as subsequent developments leading up to the outbreak of hostilities illustrate. Thus, for example, at an all-Soviet Union archaeological congress which was held in Baku, Azerbaijan in 1985, a young Azeri archaeologist (Akhundov 1985:77-8) read a paper that attempted to show that the carved stone crosses found in Azerbaijan were Albanian; that is, the products of the pre-Islamic Christian state of eastern Transcaucasia. He purported to distinguish these stone crosses from the Armenian khach' $k^{\prime}$ ar, the latter being one of the most potent symbols of the Armenian people with literally thousands of uniquely carved examples found throughout today's Republic of Armenia. Since the Republic of Armenia only occupies a fraction ${ }^{8}$ of historic Armenia, it is reasonable to assume that such Armenian khach' $k^{\prime} a r$ exist or once existed throughout areas where Armenians once constituted a major, if not the dominant, population. The young Azeri's seemingly innocuous, abstract archaeological paper was a deliberate political provocation: all the crosses on today's territory of Azerbaijan, including significantly Nagorno-Karabagh and Nakhichevan, were defined as Albanian, a people who in turn were seen as the direct ancestors of today's Azeris.

The rest, as they say, is history. The Armenian archaeologists were upset and threatened to walk out en bloc. Protests were filed, and even Russian scholars from Leningrad objected to this blatantly political appropriation, posing as scholarship. No participant in this debate would have predicted that within two years the contest over ancestral claims to NagornoKarabagh would flare up into one of the bloodiest and most significant ethnic conflicts raging within the former Soviet Union. Yet it cannot be forgotten that agitation over the status of Nagorno-Karabagh in Armenia was initiated by intellectuals, including archaeologists, familiar with and incensed by this specific insult to their cultural heritage.

Thus, minimally, two points must be made. Patently false cultural origin myths are not always harmless. The political context within which such myths are articulated is critical, and this context continually changes: given the events of the last nine years, assertion that today's Azerbaijan was the original homeland of Turkic-speaking peoples is charged with political significance. Secondly, it is incumbent upon the external observer or, in this case, foreign archaeologist, to understand this constantly unfolding political context. For one unaware of the conflicting land claims and of the 
historical tension, even antagonism, between Armenians and Azeris, one would have listened to the 1985 presentation on the stone crosses quite innocently as a legitimate attempt to distinguish Albanian from Armenian material culture. Even the most fanatical Armenian nationalist could not pretend that wherever stone crosses appear, they necessarily were carved by Armenians, a claim that would be tantamount to identifying greater historic Armenia with all of Christendom. Objectively speaking, it should be possible to examine critically the specific attributes of these crosses to define regional variants and even, with certain supportive evidence (especially inscriptions), to distinguish Georgian from Albanian from Armenian khach'k'ar. In reality, however, such a legitimate, scholarly archaeological/art historical analysis minimally requires a political environment far less impassioned than what existed in 1985, much less today.

One should not discuss the Nagorno-Karabagh issue without mentioning the deplorable practice of the actual destruction of cultural monuments (not to imply, of course, that this practice only occurs in Transcaucasia or in relation to this particular conflict; the destruction of the Islamic legacy of Bosnia represents another particularly dreadful current example of this practice (see Kaiser, this volume and MESA Newsletter 1993)). An official publication of the Academy of Sciences of Armenia (1988:21-2) claims that dozens of ancient Armenian settlements, cemeteries, khach'k'ar, and inscriptions have been destroyed during the last few decades in NagornoKarabagh and that at least thirty such monuments, including churches, have been destroyed in Nakhichevan, the detached area of Azerbaijan that physiographically forms part of the fertile Ararat valley where more than half of today's population of the Republic of Armenia is concentrated.

Before one gets too irate at the Azeris, however, one must note the paucity of surviving Islamic remains in Armenia, including the capital of Yerevan. ${ }^{9}$ To put this in historical perspective, in 1826 , before the signing of the Treaty of Turkmenchai and the ethnic movements that followed in its wake, roughly 90,000 of a total population of 110,000 in the Khanate of Yerevan were Muslims -. Persians, Kurds, and "Turko-Tatar" nomads (the last being the peoples who later became self-conscious Azeris) (Bournoutian 1983:78; and also, however, his critical review 1992:67-8). No matter what demographic statistics one consults, it is simply unquestionable that considerable material remains of Islam must once have existed in this area. Their near total absence today cannot be fortuitous.

The nationalist tenor of much Armenian archaeology is intimately associated with the recent history of the Armenians, particularly their loss 
of significant ancestral territories and massacre during World War I, events inextricably tied to the dissolution of the Ottoman Empire and the creation of the modern nation-state of Turkey (see note 4); one might even argue that the more exaggerated claims of past grandeur by Armenian nationalists are themselves a reaction to unsupportable age-old ethnic links to Anatolian prehistory by Turkish nationalists (for the latter, see McConnell 1989:109-10).

However unjustifiable. Turkey's refusal to acknowledge the statesponsored massacre of Armenians is undoubtedly fueled by Armenia's irredentist claims on large portions of eastern Anatolia, collectively referred to as western "historic Armenia." Visitors to the State Museum in Yerevan or the Armenian Ethnographic Museum in Sadarabat are greeted with large physical maps of the Armenian Highland depicting the maximal extent of the Armenian kingdom under King Tigran II (the Great) prior to their defeat by the Romans in $69 \mathrm{BC}$. Series of maps in these and other museums or for sale in local bookstores depict the inexorable, millenniaold retraction of Armenian-controlled territory over time, poignantly illustrating the tragic history of this proud ancient culture. That events in this century have significantly altered the traditional cultural geography of this area is beyond doubt; what is relevant here, however, is to determine, if possible, the proper and improper roles for archaeology in the documentation and evaluation of that history. What is the appropriate relationship between an archaeological demonstration of cultural origins and/or chronological priority in an area and territorial aspirations, including consequent state policies?

There is no easy answer, particularly since exclusive, historically justified claims to any territory, when examined critically, are nearly always questionable. When, for example, does Constantinople become Istanbul? Never; as soon as it is conquered; after 500 years (i.e., 1953 AD); after 1000 years; etc.? In other words, at what point does present cultural occupation of an area override historical claims to it? The contemporary world is replete with such examples (e.g., biblical justifications for the existence of the State of Israel; historical claims for a Muslim "Bosnian" presence in the heart of the Balkans; or even the unquestioned acceptance of the foreign occupation of the western hemisphere at the expense of its indigenous peoples). Should the maximal extent of the Armenian kingdom, which existed for less than fifty years during the first half of the first century $\mathrm{BC}$, be used as the relevant yardstick for what properly constitutes "historic Armenia"? Unfortunately, Armenian oft-expressed dreams of a Reconquista, based upon sometimes selective "readings" of the prehistoric and historic record, adversely affect relations with even potentially friendly neighbors, such as the Georgians. 
In reality, each example is so unique and distinct as to preclude generalization. Moreover, it is unclear which criterion is more appropriate: chronological priority; duration of control; or present occupation. A rchaeologists, particularly prehistorians, must be extremely careful if they attempt to enter such disputes, stating explicitly the limitations of the evidence they control.

It is not surprising that essentialist interpretations of Armenian culture and history abound. A particularly infamous "scholarly" example is S.A. Sardarian"s Pervobytnoe obshchestvo v Armenii (1967), which, besides its numerous mistakes and plagiarisms, postulates a separate Armenian race that originated on the Armenian plateau; attributes the invention of metallurgy to the Armenians; and demonstrates that the widespread Kura-Araxes culture emerged initially in the Ararat valley of Armenia. The standard of scholarship is so low and the argumentation so tendentious as to raise the question as to how the book was even published (see the devastating critique by Martirosian and Munchaev 1968:262). An even more ludicrous popular example is provided by a widely distributed publication (MESHAG n.d.) from the Armenian-American diaspora on the evolution of the Armenian alphabet, tracing its development from Palaeolithic petroglyphs through the divinely inspired invention by Meshrob Mashtots of the currently used Mesrobian script in 406 AD. Fanciful internal evolutionary development here is taken to an extreme. ${ }^{10}$

No less problematic are heavily slanted interpretations of the Urartian kingdom, the first historically attested state in Transcaucasia (ninth to seventh centuries BC). Armenian chauvinists must explain why this state, a worthy adversary of the neo-Assyrian Empire of northern Mesopotamia and one that expanded over much of "historic Armenia," composed its royal cuneiform inscriptions in Urartian, a non Indo-European (i.e., non-Armenian) language, related to Hurrian and ancestral to the Northeastern Caucasian family of languages spoken today by different peoples in Daghestan, Chechenia, and Ingushetia (see Jankowska 1991:231). Reasonable historical hypotheses can be advanced for a Proto-Armenian component to this kingdom, and there is a real sense in which the Armenians are the cultural heirs of Urartu, " but an essentialist view of Armenian culture which equates it precisely with the Urartian kingdom cannot be sustained.

One must distinguish between popular and professional Armenian interpretations of Urartu, the latter being subtler and more difficult to evaluate. Thus, popular reference to the "Piotrovskii problem" is based on the fact that B.B. Piotrovskii, the late Director of the Hermitage in Leningrad (now St. Petersburg) and former head of the excavations at Karmir Blur (the ancient Urartian capital of Teishebaine now located within the city of Yerevan), had quite reasonably maintained that the 
mighty Urartian Iron Age kingdom did not constitute the first Armenian state for the reasons stated above; the "problem" only existed for those who wanted Armenians always to have lived in and controlled "historic Armenia" until the later ravages wrought by Romans, Persians, Arabs, and Turks. More discriminating professional archaeologists, who may accept the reasonable theory that the ethnogenesis or formation of Armenian culture occurred during post-Urartian Achaemenid times, extol the might of the Urartians and see them exercising political control over most of eastern Anatolia, western Iran, and Transcaucasia; in this respect they remain the direct precursors of the Armenian kingdom under Tigran II. ${ }^{12}$

Certain words and theories are laden with political significance. Thus, the controversial linguistic theory of T. Gamkrelidze and V. Ivanov (1984), which sees the original Proto-Indo-European developing in direct association with the Proto-Kartvelian (West Caucasian) and ancient Semitic families of languages in an eastern Anatolian homeland, receives an extremely warm reception not on its linguistic merits, but on its locating Proto-Indo-European speakers in the historic Armenian heartland. ProtoIndo-European thus becomes a buzzword for Proto-Armenian. This questionable identification is transparent in tendentious interpretations of Bronze Age and later prehistoric materials from Transcaucasia, as exemplified by V.E. Oganesian's (1992) ${ }^{13}$ implausible ethnic interpretation of the fantastically suggestive iconography on a silver goblet recently excavated in the Karashamb cemetery north of Yerevan; or by G.E. Areshian's (1992:27) detailed and ingenious, albeit strained, attempt to weave together historical, mythological, and archaeological materials to demonstrate that "Armeno-Aryans" constituted "the population living in the basins of the Araxes and Kura from the end of the third millennium $B C$ " and "continuously carried out rituals connected with Indo-European cosmogonic mythology."

Ironically, chauvinistic Azeri and Armenian archaeologists alike share a need to see their people as always present in the greater eastern Anatolian/northwest Iranian/Transcaucasian region.

\section{Georgia}

During the late Soviet period, Georgia was blessed (or afflicted) with more practicing professional archaeologists than almost any comparably sized area in the world (see Lordkipanidze 1982). The works produced by these hundreds of Georgian archaeologists varied tremendously in quality with the best being exceptionally good by any standard. Even some of the most senior and responsible Georgian archaeologists were not immune to the ubiquitous temptation to identify prehistoric ethnic groups on the basis of 
their material remains and selectively to utilize incomplete linguistic and problematic physical anthropological evidence. For example, $\mathrm{O}$. Dzhaparidze's recent, significantly entitled $\mathrm{Na}$ zare etnokul' turnoi istorii Kavkaza (At the Dawn of the Ethnocultural History of the Caucasus, 1989) represents not so much an implausible, as an unascertainable attempt to identify the ethnicity and linguistic affinities of archaeologically documented cultures extending back to late Palaeolithic times. Similarly, T. Gamkrelidze's substantial linguistic reconstructions of indigenous Kartvelian (i.e., Georgian) speakers in Transcaucasia during the Bronze Age and even earlier prehistoric periods are not without political significance.

Not surprisingly, more nationalistically disposed Georgian archaeologists provide essentialist accounts of their history and culture that duplicate the same constellation of features of their like-inspired Azeri and Armenian colleagues and culminate, of course, in claims to territories that are identified as having been Georgian since time immemorial.

One significant example of this regrettable tendency concerns the history of the archaeological documentation for the tremendous florescence of Caucasian metallurgy during the late Bronze and early Iron Ages. This impressive record of metallurgical achievements first attracted the attention of the scholarly world in the late nineteenth century from discoveries made in the small village of Koban located north of the Great Caucasus range in today's North Ossetia, today a separate administrative area within Russia (Virchow 1883; Uvarova 1900). Probably the best-documented and most fully published contemporary discoveries of "Koban culture" or "Koban culture-like" materials come from the Tli cemetery, located significantly south of the Great Caucasus and made by the South Ossetian archaeologist, B.V. Tekhov, who also was very active politically for Ossetian rights and autonomy within southern Ossetia. The most complete up-to-date synthesis of Georgian archaeology, Nasledie Drevnei Gruzii (Lordkipanidze 1989:194, 196; translated into German as Archäologie in Georgien: von der Altsteinzeit zum Mittelalter (1991), see pp. 95-102 and corresponding notes), rejects in a footnote even the term "Koban culture" as a kind of archaeological misnomer due to its accidental early discovery in northern Ossetia and dismisses its rich and distinctive artistic engravings on bronze axes as a minor variant of the "Colchidean (i.e., west Georgian) culture." The marvellous materials from the Tli cemetery are scarcely mentioned in this synthesis.

That such rejection has political significance is clear when one observes that the book's basic map of the historical regions of Georgia (1989: map 1, p. 6; 1991: fig. 1, p. 3) subsumes southern Ossetia completely within Shida or Inner Kartli (central Georgia), an intentional oversight that took on new meaning with the abolishment of the Autonomous Region of South Ossetia 
by the democratically elected nationalist regime of $Z$. Gamsakhurdia in December 1990. As a reaction to this Georgian "reading" of the archaeological record, Ossetian scholars today are at pains to point out similarities between Koban materials and those from Hallstadt in central Europe, thus demonstrating that the Aryans (i.e., Indo-Europeans - now a buzzword for Ossetians)) were always present in the central Caucasus (Shnirelman, personal communication). An outsider cannot even begin to understand Caucasian prehistory and appreciate the richness of its late Bronze/Iron Age metallurgical florescence without being hyper-attuned to the political realities of even naming archaeological cultures, much less defining the area they encompassed. ${ }^{14}$

The conflict over southern Ossetia still simmers with archaeologists occasionally having functioned as "expert witnesses" on the behalf of the nationalists" debatable claim (Gamsakhurdia 1991) that the Ossetians are not aboriginal inhabitants of the Caucasus ${ }^{15}$ since they were only first pushed into northern Caucasia in the wake of the Mongol and Timurid invasions of the thirteenth and fourteenth centuries and then migrated south across the Caucasus range into historic Georgia first during the seventeenth and eighteenth centuries. Phrased politely, this revisionist historical account is open to serious criticism (see, for example, the much more balanced archaeological reconstruction of the ethnogenesis of the Ossetians by E.I. Krupnov (1960:390-3)). Even if true - and this is perhaps an even more important point - this revisionist dismissal of the Johnnycome-lately Ossetians begs the question of how many centuries, how many human generations, are necessary to have a legitimate ancestral claim to a piece of property. The point is not to belittle a complex issue, but to illustrate that archaeology can be knowingly manipulated to provide a politically correct "reading" of the past that then serves as a pretext to uproot and kill people living in an area minimally for several centuries.

The Djavakheti (or Djavakheti/Meskheti) region of southern Georgia (see Map 2) provides an almost textbook illustration of the complexities of historical/archaeological claims to a specific territory. The region is filled with beautiful Georgian medieval monuments, such as the Wardzhia cave monastery complex, most of which date to the tenth to twelfth centuries but some of which go back even earlier to the fifth and sixth centuries. Today's population is dominantly Armenian, probably exceeding 80 per cent of the total in eastern Djavakheti which borders northwestern Armenia. The recent history of the area is reasonably well known: Turks ruled southern Georgia from 1578 to 1828 and the Georgians who had been living there either left or were Turkicized. ${ }^{16}$ With the signing of the same treaties that affected the ethnic composition of today's Republic of Armenia, Armenlans from eastern Anatolia moved into this underpopulated area, preferring to live under the Christian tsar than under the Ottoman sultan. 
Archaeologically, these events can be well documented, particularly by the construction of nineteenth-century Armenian churches on top of or next to the much earlier medieval Georgian churches. A history that only stretches back to medieval times, however, is insufficient for the local inhabitants, who ask, as soon as one enters one of their villages (Armenian or Georgian), who was there first, the Armenians or the Georgians. The practice of archaeology in southern Georgia cannot be divorced from this tense political context.

One must also distinguish an archaeological or historical identification of a people from current state policies affecting that people. What happened in the distant past is not the only, nor typically the most important, factor to consider in trying to understand, much less resolve, difficult territorially based ethnic disputes. Consideration of the historical archaeology of southern Georgia documents clearly that a legitimate historical claim $^{17}$ to this territory can be maintained by the Georgians. The ethnicity of the people who dominantly occupied this territory during Iron Age and classical times (including under the undoubtedly multi-ethnic reign of Tigran the Great) is unknown, and even the hypothetical (and improbable) discovery someday of inscriptions proving that most peoples in the area then spoke an Indo-European, Proto-Armenian, or Armenian-related language would not erase the Georgian historical claim to the area. This conclusion follows directly from the point made earlier about the everdeveloping nature of cultures and the fact that Christianity has been an integral component of both Georgian and Armenian cultures for centuries: one simply cannot ignore those beautiful monastery complexes and churches with their Georgian inscriptions.

Admitting this, however, does not provide an excuse for the current Georgian state policy of deliberately underdeveloping the area and hindering communications and transportation between the local Armenian populations and their ethnic relatives to the south. Surely many generations of Armenians have lived and died on this soil since arriving en masse after 1828 , and this fact alone is obviously relevant to their just treatment and the rights that they deserve. ${ }^{18}$ The Bible or even biblical archacology may be invoked to legitimize an historical claim to the West Bank, but such a claim does not provide justification for a specific state policy of uprooting Palestinian orchards and olive groves or demolishing their homes. These issues must be kept separate, and any honest archaeologist should be capable of distinguishing between them.

The bewildering array of peoples in northern Caucasia coupled with their relatively short historical record means that prehistory here is once more 
implicated in questions of ethnogenesis and claims to specific territories (for a recent historical introduction to this poorly known area, see Broxup 1992). The region today is characterized by ethnic tensions, occasionally breaking out into open hostilities (e.g., the conflict between the northern Ossetians and the neighboring Ingush, who, in turn, find themselves divorced from the Chechen to their east), and it is unclear at this writing whether further Balkanization of the region will continue or whether an effective federation of north Caucasian peoples will emerge (Ormrod 1993).

As to be expected, essentialist cultural interpretations abound which often are coupled with selective presentations of dubious linguistic evidence to "prove" diametrically opposed "readings" of the prehistoric record. Thus, we learn that the creators of the Maikop culture wrote in a previously unrecognized Abkhazian script (Turchaninov 1971) or that this same archaeologically documented culture bears material witness to supposed linguistic convergences and hence genetic relationships between Sumerian and Karachai-Balkar, that is, early Turkic (Miziev 1986; for devastating critiques of these unbelievable "readings" see particularly the reviews by Chechenov and Markovin in Balzer 1992). Periodically, "archaeologists" or "philologists" of Lezghin ethnic background or of one of the linguistically related smaller peoples of southern Daghestan and northern Azerbaijan (e.g., Udi) report the discovery of new or hitherto unreadable inscriptions which purportedly demonstrate that their ethnic group is the direct descendant of the Albanians and/or Urartians, peoples who once controlled extensive lands to the south; such claims are either fabricated wholesale or remain essentially unsubstantiated, despite the fact that most objective linguists would concede the historical likelihood that there were such genetic links to one or more of these peoples. The archaeological record is further complicated and politicized by documentable relations with steppe cultures to the north, including those elusive Proto-Indo-European speakers (for new evidence possibly documenting such connections, see Rezepkin 1992). In short, archaeology in the northern Caucasus occasionally exhibits on a smaller scale the same distortions and politically motivated features that characterize its practice farther south in Azerbaijan, Armenia, and Georgia and should be criticized along the same lines.

\section{Nationalism in the classical archaeology of the Caucasus: Greeks and "Georgians" in ancient Colchis}

The interpretation of the later archaeological record in the Caucasus is also suffused with nationalist sentiments. The second part of this paper presents a detailed example of this practice: the denial of significant Greek 
influences on the local archaeologically attested cultures of western Georgia (ancient Colchis). Despite their historically checkered relations, Georgians and Greeks are not currently killing each other over conflicting ancestral claims. This case study represents neither the only, nor the most invidious example of nationalist archaeology in the later historical archaeology of the Caucasus. It does, however, nicely illustrate the pervasive extent of nationalist prejudice: implausible archaeological reconstructions, extolling the glory of all things indigenous while disparaging the influence of external contacts, dominate less partial, more sober and objective "readings" of the same rich body of archaeological and written sources.

In the West the term "classical archaeology" refers to Greek and Roman antiquities; in the former Soviet Union, the Russian word antichnaya is used for this period. Although use of this term typically is clear and unproblematic, it recently was suggested that the term antichnaya arkheologiva is inappropriate for the archaeology of Georgia and ought to be replaced by the term "Iberian-Colchian period" which extended in three sub-periods from the seventh century BC through the fourth century AD. According to the author, the reason for this substitution was that the term antichnaya arkheologiva is used in relation to Graeco-Roman sites, while in the territory of ancient Georgia only Greek and Roman trading colonies are to be found - there never having been a permanent Graeco-Roman population (G. Gamkrelidze 1985:123-6). This article did not elicit responses or commentaries from Georgian specialists in the field, though their lack of response does not mean that they did not agree with the author. Questions as to the presence of the Greeks in ancient Colchis, the Greek colonization of this region, and the influence of Greek culture on the indigenous inhabitants of Colchis are fiercely debated among Georgian archaeologists, and the only convincing explanation for controversy over what should be non-problematic is national pride.

Similarly, nationalist emotions predominate in the writings of local historians. In July 1991 an article appeared in a district newspaper in the town of Kobuleti about the name of the fortified settlement of Petra (Kontselidze 1991), one of the most significant archaeological sites in western Georgia. In the sixth to second centuries BC a Colchian/Greek settlement existed there; in the first centuries AD there was a Roman military settlement; and in the middle of the sixth century AD the Byzantines fortified the previously existing settlement and named it Petra. Kontselidze believes that this fortress should be renamed, since the name Petra is Greek and it had been built not by Georgians but by the Byzantines for themselves. He is distraught that professional archacologists and historians are unable to find the Gcorgian name of this fortress. 
The vast majority of Georgian (and some Abkhazian) archaeologists do not want to accept the Greek colonization of Colchis or the influence of Greek culture on Colchis. Some scholars even place the term colonization in quotes (e.g., Kaukhchishvili 1979:274). According to them, the Greeks did not found independent Greek colonies (poleis), but factoria for trade which did not have a chora (or agricultural hinterland). These factoria were under the control of the local Colchian rulers and either were small settlements or constituted districts of local towns. In order to substantiate these conclusions, it is argued that there existed a strong local state with a king in Colchis and that this state stood in the way of the emergence of independent Greek cities. Greek influence on the material and nonmaterial culture of Colchis is also denied (at least in the sixth to fourth centuries BC) by reference to the fact that Colchian culture was highly developed and did not need to accept anything from Hellenic culture which was alien to it (Lordkipanidze 1989:256-72). ${ }^{19}$ We shall not examine in detail the question of the Greek colonization of Colchis but attempt to paint a general picture of the eastern part of the Black Sea region in the sixth to fourth centuries BC (for more information, see Tsetskhladze 1994).

The problems of the Colchian state and royal power in Colchis

Most Georgian scholars consider that a strong local state had emerged in Colchis at least by the end of the sixth century BC. Herodotus' account seemingly supports this opinion:

The Persians live right up as far as the Southern Sea, known as the Red Sea [i.e. the Persian Gulf]; beyond them to the North live the Medes, beyond them the Saspiri, beyond the Saspiri are the Colchians, whose land reaches as far as the Northern Sea [Black Sea], into which flows the River Phasis. These are the four pcoples whose lands stretch from one sea to the other. (IV.37)

From this passage, the following conclusion is drawn:

Within this extensive territory the "father of History" [Herodotus] places only four peoples: the Persians; the Medes; the Saspiri; and the Colchians. It is well known that the states of the Medes and the Persians at that time were powerful, and the fact that the Colchians are mentioned in the same breath can probably be seen as an indirect indication of the fact that there also then existed a state of Colchis that was a large political entity. (Lordkipanidze 1989:220-1)

Such wishful thinking, however, is not really plausible. Mention of the Colchians alongside the Persians and the Medes need not indicate that the Colchians had a strong state-structured polity. If the same logic were to be followed further, one would be forced to assume that the Saspiri also had a 
strong state. More revealing is the note by the same scholar which refers to the Saspiri as "East Georgian [sic:] tribes" (Lordkipanidze 1989:221, note 20). In reality, Herodotus was simply listing these peoples according to their geographical location and not according to the extent of their population, nor to their control of large political states. Ancient authors are not cited for documenting royal power in Colchis; instead, we are informed that the descendants of King Aeetes ruled in Colchis and that later rulers inherited his throne (Lordkipanidze 1989:223 4). Scholarship here devolves into mythology.

Greek and Roman authors always showed an interest in Colchis, above all as the Land of the Golden Fleece and the home of Medea, and, for this reason, kept retelling parts of the myth of the Argonauts. There simply is very little reliable and concrete historical information about Colchis in the Greek literary tradition. One cannot reconstruct the social structure of the "erstwhile mighty Colchian Kingdom," as based, for example, on the Argonautica of Apollonius Rhodius (Lordkipanidze 1989:229), but only evaluate as critically and as objectively as possible the archaeological record and the more reliable historical sources.

Archaeological materials, primarily mortuary evidence, reveal marked social differentiation and the emergence of a local Colchian elite in the late sixth and early fifth century $\mathrm{BC}$, and it is probable that a Colchian state, ruled by a king, existed at that time. The question then becomes: how centralized and powerful was this state? Written sources are helpful and indicate that Colchis was not a centralized state. Strabo, whose information on Colchis is always reliable, wrote that "the kings, ruling over a land divided up into skeptouchs, enjoyed a moderate degree of power" (XI.2.18). This passage testifies to the fact that Colchis was divided up into administrative/territorial units (skeptouchs) headed by skeptouchoi (a title based on the ancient Greek word meaning "scepterholder"), who were representatives of the local clan-based aristocracy. "Colchis" itself was not an ethnic but a political term; it was an alliance of numerous Colchian tribes and not a unified, centralized kingdom.

\section{$B$}

\section{The question of Greek colonization}

According to the classical authors, three cities were founded by the Greeks in the region known as Colchis: Phasis, Gyenos, and Dioscuria. Admitiedly, the archaeological evidence is problematic: Phasis has not been found: part of Dioscuria lies under the Black Sea and the rest is under the modern, now war-ravaged city of Sukhumi: and Gyenos has not been systematically investigated. Nevertheless, consideration of the relatively unambiguous and substantial historical record reveals that one cannot seriously question 
the existence of these poleis in Colchis, nor pretend that the Greeks only traded there.

We know that Phasis was founded by Milesians (Heraclides Ponticus, XVIII; Pomponius Mela, I.108; Anon. PPE, 44; Stephen of Byzantium s.v. Ethnika). Written sources provide the founder's name - Phemistagoras of Miletus (Pomponius Mela, I.108), the leader of the colonists. Pseudo-Scylax refers to it as an Hellenic city (81). A fragment of an "Aristotelian Constitution of the Phasians" (FGr Hist. II, p. 218) is a particularly important Greek source. Although the interpretation of this text and the translation of certain words are controversial, one fact is incontrovertible: the city of Phasis was a Milesian colony that had its own constitution, which attracted the attention of Aristotle, whose writings include descriptions of the constitutions of such poleis as Athens, Sparta, and Miletus. In Phasis the colonists were responsible for introducing the cult of Apollo, and a temple dedicated to that Greek god existed in the city. The city also minted its own silver coins - the so-called Kolkhidki (Dundua 1987:9-33).

Gyenos was also an Hellenic polis (Pseudo-Scylax, 81). The archaeological materials reveal that it too was founded by the Milesians. That same Greek city also founded Dioscuria, whose chora also has been documented. Appian (101), Charax of Pergamum (Frg. 36, 37 v), Pliny (Natural History, VI.61), Pomponius Mela (I, III) and Ammianus Marcellinus (XXII.8.24) link the name of the city "Dioscuria" with the name of the Dioscuri Castor and Pollux - and are of the opinion that it had been founded in their honor. All the above-mentioned Greek cities were established in the middle of the sixth century $\mathrm{BC}$, and they functioned as trading centers for the local tribes. Apart from these cities, there were also Hellenic settlements at Tsikhisdziri and Pichvnari (Tsetskhladze 1994).

It is difficult to understand why the local royal power in Colchis would have impeded the emergence of independent Greek poleis. The king and the local elite had every reason to be on good terms with the Greeks. The Hellenization of the elite began immediately, a process clearly reflected in the archaeological materials, most of which are found in Vani, a city-site inhabited by many nobles. It was precisely in centers such as these that craft production was concentrated, particularly in those spheres of production that provided for the needs of the ruling elite of Colchian society, such as. above all, the production of seal-rings as distinctive emblems of the elite. Greeks were working in the workshops -- a fact universally accepted, even by nationalist-minded Georgian archaeologists. Although at present it is impossible to trace precisely and consistently the development of Georgian glyptics or to speak of a definite "Colchian" or "Graeco-Colchian" style in glyptics, systematic study of certain characteristic groups of intaglios has 
made it possible to pick out certain features and to distinguish preliminarily between Colchian and Graeco-Colchian seals.

The next "elite" branch of artistic craftsmanship that catered to the local rulers was goldsmithing. The written and archaeological sources together confirm that this type of craft production was not imported. It is difficult to say who was engaged in these gold workshops. The typology of the gold articles (e.g., earrings, diadems) shows that local craftsmen played the dominant role. but Greek influence is also evident. Granulation was widespread both in the classical world and farther east, and artistic analysis reveals Oriental influences (e.g., the depictions of fighting animals on diadems). The predilection of the ruling elite with regard to gold jewelry was the same everywhere. Some gold articles were gifts from the Achaemenid kings, and it is clear that others had been received by the local rulers as gifts from Greek merchants, a pattern also seen in the ornamental metal reliefs. Furthermore, the elite immediately began to use the Greek language; study of the graffiti reveals that the elite wrote in Greek (Tsetskhladze 1994; for more details on problems with the interpretation of Achaemenid materials, see Tsetskhladze 1992).

\section{The influence of Greek culture on Colchian culture}

Some Georgian authorities have maintained that there was no significant Greek influence on the material culture of Colchis in the sixth to fourth centuries BC, such as in craft production, building techniques, funerary rites, domestic life, and the like (Lordkipanidze 1989:261). Rather than considering all these manifestations of material culture, let us turn our attention to just one aspect: the funerary rituals practiced by the local population. This phenomenon is most revealing in that ideology and religion are always conservative forms of material and non-material culture; if the influence of Greek culture made itself felt here, then this strongly suggests that the Greek presence in Colchis was significant.

Interesting materials have been brought to light by excavations of a Colchian cemetery dating from the fifth century $\mathrm{BC}$ which was discovered at Kobuleti-Pichvnari. The orientation of 103 of the 160 published burials has been established, and forty-two of these exhibit an orientation towards the east as was typical for the Greeks. We also encounter the "Charon's obol" ritual: forty-nine coins were found in nineteen of the 160 burials, one of them being from Sinope while the remainder were Colchian. Hellenic influence also serves to explain the presence of amphorae in six burials. The amphorae are from Chios and Phasos, apart from one which is proto-Phasian. One also must emphasize that similar materials from Tsikhisdziri show that the cemetery of Pichvnari is not the 
only place documenting the actual physical presence of the Greeks in Colchis.

Finally, while nothing is known about the local language, it has already been established that the official language for religious ceremonies and state administration in Colchis was Greek. This has been demonstrated by the find of official political and religious decrees written in impeccable Greek on bronze sheets in Eshera and Vani (Tsetskhladze 1994).

In short, what for all other people and states is seen as a source of pride namely, direct contact between their culture and Graeco-Roman civilization - is unacceptable for certain Georgian archaeologists. Facts, however, should prevail over nationalist emotions. Scholars, who should serve Clio and not contemporary politics, must free themselves from prejudices that reflect nationalist feelings and current events. Today no-one doubts that a highly developed civilization existed in the first millennium BC within the territory of what is now western Georgia, a culture which at the same time enjoyed close political, economic, and cultural links with both the Mediterranean and the Eastern (particularly the Achaemenid Empire) worlds. Like any other highly developed culture, Colchis absorbed and refashioned the achievements of the Greek and Achaemenid civilizations. This should be seen as progress, not the opposite.

\section{Conclusion: the preferred "reading"}

The prehistoric and early historic archaeological record of the Caucasus is consistently distorted for nationalist reasons. Thus, the earliest evidence for domestication, for full-scale metallurgy, for monumental architecture, etc. - all find their origins in that remarkably creative cradle nestled along the western shore of the Caspian (for an Azeri), in the lush foothills of the Great Caucasus and along the Black Sea coast (for a Georgian), or in the fertile Ararat valley of southern Transcaucasia (for an Armenian). Hyperbole, of course, is a trait not unknown to archaeologists and does not always illustrate the politicization of the discipline. But it happens so consistently throughout the Caucasus that one is tempted to despair of ever sifting through these claims and counterclaims to determine "objectively" from the known record the earliest or most complex manifestation of specific archaeological cultures. Nationalist-inspired interpretations of the archaeological record greatly complicate any attempt to understand or synthesize the prehistory and early history of the Caucasus.

Consideration of the extremely politicized nature of Caucasian archaeology, however, reveals far more serious problems than simply trying to determine more objectively prehistoric and early historic developments throughout the area. The recurrent, blatantly political interpretations of 
archaeological materials illustrate clearly why one should abandon the dangerously naïve position, advocated by some post-processual archaeologists, that one's or one people's "reading of the past" is as valid and justifiable as another's. Such "readings" of the Caucasian evidence have been used to destroy the cultural legacy of others or to uproot and kill local peoples who have been living in specific areas for centuries. Archaeologists must adopt more universal criteria which emphasize the common cultural heritage of the area in which they work, if not the common cultural evolutionary history of humankind in general.

The "story" that needs to be written about Caucasian archaeology is one that emphasizes the eminently documentable sharing of material culture traits throughout the region at least since the beginnings of the Bronze Age. Such sharing reveals a common historical legacy that defines a very rich Caucasian culture area. However imperceptibly, such a "story" and others like it might help bring together the numerous peoples of the Caucasus so that they can face together a very uncertain but exciting political future and confront together the ecological problems that will continue to beset their beautiful environment well into the next century.

\section{NOTES}

1 This article is an expanded version of the paper "Nationalism, Politics, and the Practice of Archaeology in Transcaucasia" presented by Philip L. Kohl at the American Anthropological Association meetings in Chicago, Illinois in November 1991 and published in the Journal of European Archaeology 2 (1993), 179 86. Several individuals read earlier versions of this paper and made many useful comments and provided additional references. We thank them all and particularly wish to acknowledge the thoughtful suggestions of V. Shnirelman and M.I. Martínez Navarrete. Andrea Finn drew Map 1. The prehistoric section of this paper (part I) was written by P.L. Kohl, while the treatment of classical archaeology in Georgian archaeology (part II) was written by G.R. Tsetskhladze.

2 Since one of the principal points of this paper is that archaeologists must be aware of the political implications of their work, including the connotations of even the terms they employ, we must note that the geographical designations Ciscaucasia and Transcaucasia have as their referent Russia (if not Moscow) which is located, of course, north of the Great Caucasus range. Although problematic, these terms occasionally are used here for convenience and because they are so enshrined in the Russian literature.

3 At the time of the basic revision of this article (spring 1993), such claims were not being articulated for the reason that Azerbaijan secks Iranian assistance in its conflict with the Armenians. Such silence, of course, does not imply a renunciation of "northern Azerbaijan"s" territorial aspirations in "southern Azerbaijan." Like many of the nationalist leaders that have emerged in the post-Soviet period, including President L. Ter-Petrosian of Armenia, the former 
Azerbaijani leader maintains a keen interest in his "reading" of history (and prehistory).

Many very scholarly works on Azerbaijan (e.g., Altstadt 1992) are misleading in their almost exclusive focus on "northern Azerbaijan." Reading them, one would never appreciate that Azeris living in Iran are far more numerous than their northern relations (upwards of $10,000,000$ people), form the second largest ethnic group after the Persians in the country, and have during many periods, such as under the Qajar dynasty, dominated the internal affairs of Iran.

4 The denial of Armenian history is not an exclusively Azeri practice. Armenian cultural remains in neighboring eastern Turkey are frequently dismissed or referred to as "Ottoman period" monuments. The continued denial of the wholesale state-sponsored massacre of at the least several hundreds of thousands of Armenians carlier this century (the Armenian genocide of 1915) and their forced expulsion from ancestral homes in castern Anatolia is, of course, related to these practices. It is doubtful that the practice of archaeology in Azerbaijan, Armenia, or Turkey will ever be de-politicized without some official acknowledgement of this horrible historical tragedy inflicted on the Armenians by the then Turkish government. While one should not justify this refusal to acknowledge a terrible past, admission of these events in Turkey apparently is complicated by the fact that many historical figures still important in the construction of Turkish national identity are implicated in the 1915 slaughter of the Armenians.

5 The date for the emergence of the Azeris as a distinct, conscious ethnic group is variously set by different authors, some of whose political agendas are manifest (c.g., compare the contrasting views of Alekperov and Alijarov in Balzer and Paksoy 1990). Western scholars, such as T. Swictochowski (1983) and A. Altstadt (1992), associate this development with Azeri intellectuals' aspirations for modern nationhood, placing it either at the end of the nineteenth or the beginning of the twentieth century (i.e., quite late), the latter specialist even preferring the term Azerbaijani Turk to Azeri or Azerbaijani (p. xix). Swietochowski (1983:231) writes:

In 1905 Azerbaijan was still merely a geographical name for a stretch of land inhabited by a people whose group identity consisted of being Muslims. The period between this date and the fall of the independent Republic in 1920 witnessed the rise of. for the Muslims, a novel type of community, the nation... Against this backdrop [the cataclysmic events of the early twcntieth century], the universalistic umma consciousness was giving way at least among the intelligentsia to Turkism, and the next stage in the evolution was Azcrbaijani nationalism.

To utilize the Soviet anthropological parlance, the ethnogenesis of the Azeri people effectively has only occurred during the last 100 years.

6 Of course, not all anthropomorphic stones set over graves represent remains recording the movement of Turkish peoples. As with most material markers, the archaeological record is more complicated. Stylized human-shaped gravestones are found cven in early Bronze Age contexts in the Caucasus, and, in the absence of supporting materials, questions naturally arise as to the date of spccific monuments. This problem, which is similar to that of interpreting carved cross-shaped stones (sec below), can be reasonably solved through traditional art historical and archaeological analysis. 
7 Upon querying the date for the initial appearance of Turkic peoples in Transcaucasia, one of the authors of this article (PLK) was informed by two archaeologists from the Institute of History in Baku in 1986 that many scholars in Azerbaijan thought that Turkic-speaking peoples had always lived there. that, in short, the Urheimat of Turkish-speakers was contemporary Azerbaijan, a belief that contradicts all historical and archaeological evidence.

8 Some Armenian irredentists insist that today's Armenia is only one tenth of "historic Armenia," a claim which also deserves critical scrutiny (see note 17 below).

9 One surviving mosque in Yerevan functions today as the city museum of Yerevan. Plans were developed for the Iranians to restore this mosque as part of a cultural/economic agreement between the two countries. In return, the Armenians were supposed to restore an Armenian church in Iran. It is unknown whether this agreement will be actualized, particularly given the current deterioration of relations between the countries which is associated with the war in Nagorno-Karabagh and the Armenian offensive into western Azerbaijan.

10 One of the authors (PLK) recalls his guided tour of the rich, handsomely displayed Ethnographic Museum at Sadarabat (which is located on the western edge of the fertile Ararat valley at the place where the Armenians defeated a Turkish army in 1918, preventing further catastrophe and an cven greater Armenian diaspora). The overly enthusiastic guide explained that all the crafts and materials on display, such as carpets and even the fez or hat worn by males throughout the Ottoman Empire, were invented by Armenians. This essentialist interpretation of Armenian culture not only posits a separate evolution for the Armenian "race," but also grants them chronological priority in most significant cultural achievements which throughout history they then passed on to the less civilized barbarians surrounding them. Needless to say, their neighbors resent such claims, regardless of whether or not they can be historically verified.

Debates between Armenians and Georgians, for example, over who was responsible for innovations in carly medicval Christian architecture seem absolutely puerile to an outsider but, unfortunately, sometimes have tragic consequences. (Sce Yakobson's sensible review [1968] of the Georgian chauvinistic study by G.N. Chubinashvili Searches for Armenian Architecture [1967]. We thank Dr. S. Aslanian for providing this reference and that of the previously mentioned review by Martirosian and Munchacv.) One wonders whether the early Christian communities in the Caucasus were as obsessed with ethnicity as their twenticth-century descendants; the "scholarly" debate among contemporary Armenians and Georgians over priorities in Christian architecture recalls the competing ethnic claims for the origins of Insular art in northwestern Europe (and the sensible criticisms of them by Wailes and Zoll, this volume).

One must avoid any temptation to ridicule the exaggerated, sometimes patently false claims to great antiquity associated with the essentialist vision of Armenian culture. As R.G. Suny (1993a:4-5) sensitively observes:

An cssentialist view of Armenians... has been for political nationalists the basis for their political ideology: the continuous existence of the Armenians as a historic people. their 
origins in the Armenian plateau, arms them with the right of self-determination, nationhood, and a historically sanctified claim to the territories that constitute Armenia. Because this view of Armenian history plays such an important role for Armenians (as homologous views play for Georgians, Azcrbaijanis, Turks, and other peoples), any attempt to dispute it, to decompose the collection of beliefs that make up this reading, must be done with care and sensitivity, with full awareness that such an investigation may be perceived as an attack on the very soul of the nation.

This entire critique of essentialist accounts of Azeri, Armenian, Georgian, and north Caucasian archacology is made with this awareness and, hopefully, with the care and sensitivity that Suny rightly recommends.

11 And in the same sense, of course, the Azeris can be considered the cultural heirs of the Albanians, as well as of the other peoples who once occupied today's territory of Azerbaijan. I.M. Diakonoff concludes his brilliant linguistic study on The Pre-History of the Armenian People (1984:129-30) with the following obscrvation:

it is evident that the history of the Armenian people is a direct continuation of the history not only of the Proto-Armenians [prior to the formation of the Armenian ethnos proper, probably in the sixth century BC], but also (and to no lesser degree) of the Hurrians, the Urartians, and the Luwians. The main mass of the Armenian nation consists of their descendants; there was a historical moment when a person might speak Old Armenian, his father, grandfather, or great-grandfather was more likely to have been bilingual, while his forefather was a pure Hurrian or Urartian ... There is no question but that ancient Armenian history can correctly be understood only as the continuation of the more ancient history of the Hurrians and the Urartians, as well as that of the Luwians.

But he also emphasizes (p. 128):

the cnormous cultural impact the Urartian state and culture ... had beyond the confines of the Urartian linguistic territory proper. In this sense the cultural heritage of Urartu is the property of all the peoples of Transcaucasia and not of the Armenian nation alone. (italics added)

His study convincingly refutes various chauvinist attempts to cquate the ProtoArmenians with various mentioned peoples in cuneiform and classical sources (e.g., Kavoukjian 1987) and postulates, on the basis of linguistic affinity between Proto- and Old Armenian and Thracian and Phrygian, a movement of Proto-Armenian speakers west to cast across the Anatolian plateau during the second millennium $\mathrm{BC}$.

12 An Armenian archaeologist specializing in the late Iron Age and classical periods informed one of us (PLK) that the Urartian state had extended as far north as the southern banks of the Middle Kura river (a belief not confirmed by Urartian inscriptions or, indeed, by even less certain material evidence); a politically attuned - if skeptical - interpretation of this claim would view it as a possible subconscious justification for Armenian dominance in Tiflis, which actually was the case for much of the nineteenth century but which was not true centuries carlier, nor today when Tbilisi is the capital of Georgia. Another Iron Age specialist claimed that the Urartian rule had extended at least as far north as the Tli cemetery in southern Ossetia (or Inner Kartli, see below), since Urartian or Urartian-inspired materials, such as figured bronze belts, had been excavated in this cemetery. A less chauvinistic "reading" of this same evidence would consider such items as imports or imitations from the Urartian world, since the 
Lrartian connections are relatively rare in the rich, clearly local assemblage of materials from this cemetery (see Tekhov 1980, 1981, 1985, 1988 and below).

13 Another indication of the politicized nature and importance of archaeology in many countries throughout the world (though not in the United States) is the recurrent fact that archaeologists often assume major political roles. Examples (e.g., Y. Yadin in Israel) of this phenomenon are too numerous to recount: suffice it to say that archacologists, ancient historians, linguists, ethnographers, folklorists, etc. are playing a major role in current political developments throughout the Caucasus (and indeed the former Soviet Union), particularly those associated with various nationalist movements (Chernykh, this volume). That V.E. Oganesian today is one of the leaders of the Dashnaktsutiun nationalist party in Armenia is not irrelevant to his Indo-European "reading" of the Karashamb silver goblet. To paraphrase E.H. Carr's famous maxim, study the archacologist before you begin to study his/her presentation of the archaeological record.

14 Similarly, given the incredibly tense political context of ethnic conflicts ranging throughout Gcorgia, including most tragically at the moment the Georgian/ Abkhazian conflict, one must not ridicule or lampoon what appear to be ludicrous evaluations of the prehistoric record; rather one must appreciate them sensitively and sympathetically in light of this context.

15 Extreme Georgian nationalists distinguish the non-aboriginal Ossetians from the aboriginal Abkhazians of today's northwestern Georgia; current territorial conflict with the latter cannot be justified on the same ideological grounds, making this conflict more theoretically complicated and ambiguous.

16 Many of these Meskheti in turn were deported by Stalin to central Asia in 1944, illustrating vividly "the making" of the contemporary Meskheti ethnos; forced deportations, of course, constitute one of history's best-documented means for increasing a culture's sense of group self-identity and consciousness. Today tens of thousands of Meskheti, some of whom have Georgian surnames but profess Islam and speak Turkish, aspire to return to their "homeland," creating yet another serious ethnic problem for the nascent Republic of Georgia (Lomsadze 1989).

17 By the same token, of course, the Armenians have a legitimate historical claim to a core or heartland area of "historic Armenia" stretching at least from Van to Erzerum and north to include their medieval capital of Ani. The great difference, of course, is that this heartland was effectively "cleansed" of Armenians in 1915 and has been both de facto and de jure controlled by Turkey since the signing of the Treaty of Lausanne in July 1923. This difference in political control and the historically shaped realities of population distributions and the like that ensued create a different dynamic, far less tractable to a "just" solution. Nevertheless, one can maintain that the legitimate historical claim of Armenia to a core or heartland area in eastern Anatolia is one factor - among many others - that must be considered in trying to temper or resolve the long-standing enmity between the Armenians and the Turks.

18 Under the nationalist government of Z. Gamsakhurdia, the attempt was made to deny rights of eitizenship to those inhabitants of Georgia who could not demonstrate their existence on Georgian soil as Georgian speakers before 1801 , 
a particularly insidious state policy.

19 One should mention that some Georgian archaeologists refer to a Bronze Age Colchian state, making it the earliest complex society in Transcaucasia. Here the competition once again is with the Armenians and their claims for this distinction: i.e., Urartu or even pre-Urartian states in the Ararat valley (Shnirelman, personal communication). 


\section{University Library}

\section{- M M I N E R VA A gateway to Melbourne's research publications}

Minerva Access is the Institutional Repository of The University of Melbourne

Author/s:

Kohl, Philip L.;Tsetskhladze, Gocha R.

Title:

Nationalism, politics, and the practice of archaeology in the Caucasus

Date:

1996

Citation:

Kohl, P. L., \& Tsetskhladze, G. R. (1996). Nationalism, politics, and the practice of archaeology in the Caucasus. In P. L. Kohl (Ed.), Nationalism, politics, and the practice of archaeology (pp. 149-174). Cambridge: Cambridge University Press.

Publication Status:

Published

Persistent Link:

http://hdl.handle.net/11343/33015 